\title{
Internet Censorship in the Context of Legal Regulation in Russia
}

\author{
Gaydareva I.N.* Eshev M.A. Markov P.N.
}

\author{
Adyghe State University, Maykop, Russia \\ *Corresponding author.E-mail: alay_1968@mail.ru
}

\begin{abstract}
This paper discusses the problem of the implementation of Internet censorship in the process of legal regulation. Freedom of speech is the bases for the development of personality, which is the grounds for discussing the problems of the modern world, such as restricting freedom on the Internet. The paper emphasizes legal acts and declarations that oppose the restriction of freedom on the Internet, as well as some discrepancies between legislation and the real situation. It is noted that under the conditions of the modern development of society, there is a problem of legal regulation of the order, conditions for the use of telecommunication networks and the protection of the rights and legitimate interests of various entities in the circulation of information in global computer networks. The authors emphasize that taking into account all the positive aspects that make society more open, free, and modern, the Internet also includes a very dangerous segment generating a high degree of vulnerability of public and state interests. In this regard, most states are trying to clearly establish the framework of what is permitted on the Internet, to determine the types of responsibilities for offenses in this area, and to establish sanctions at the legislative level.
\end{abstract}

Keywords: Internet, human and civil rights, law, legal regulation, freedom of speech, censorship

\section{INTRODUCTION}

In the 21 st century, humanity is striving for a post-industrial society through the development of technology. Globalization processes have significantly accelerated the development of communication technologies for linking the whole world. This has become the driving force to create the Internet. Humanity has received a huge platform for the free receipt and publication of information. Recently, however, it is possible to observe the formation of certain trends towards legislative consolidation of Internet censorship.

One of the most important signs of a democratic state is the presence of a legally consolidated and real freedom of speech and thought exercised by citizens. In modern Russia, in our opinion, the processes of building a legal and democratic state are at the stage of establishment. As a result, attempts to officially enforce censorship of the Internet space may adversely affect the development of these processes.

The word "censorship" came from the Latin word "census," which in ancient Rome meant a periodic system of property valuation for dividing people into classes [1, p. 81]. The Roman censor monitored the trustworthiness of Roman citizens. Ozhegov's Explanatory Dictionary defines censorship as "viewing papers intended for publication, stage production, etc., as well as correspondence from time to time, for the purpose of supervision."

The broad sense of censorship is interpreted by I. Ye. Levchenko. Following Levchenko's thoughts, censorship is a sociocultural system of control over the production, distribution, storage, and consumption of social information, acting in accordance with the needs and interests of the organizing and directing authority vested with power [2, p. 74].

In its various manifestations, censorship is somehow opposed to freedom. In this regard, for the further revelation of the selected topic, it is logical to talk about the very concept of "freedom."

In the general philosophical sense, freedom means a person's right to choose from several behaviors, while acting independently and without coercion. Of course, absolute freedom is possible only in the thoughts of man. Morality and law are some of the constraints. "Morality restricts free will and defines, forms positive freedom as the ability to assert the truth, goodness, beauty, and contrary to circumstances. This differs positive freedom from freedom of arbitrariness as overindulgence" [3, p. 635].

In the context of globalization, freedom seems to be one of the most important topics for understanding because the boundaries between citizens and the state are erased, new methods of control over the population and the disappearance of barriers to private life emerge. Freedom is required for the planned and comprehensive development of a person as an individual [4].

From the point of view of constitutional law, the concept of "freedom" was first revealed in the French Declaration of the Rights and Freedoms of Man and Citizen, "Freedom consists in the ability to do everything that does not harm 
others, thus, the exercise of the natural rights of every person is limited only by those boundaries that provide other members of society with the use of the same rights. These boundaries may only be determined by law" (Article 4) $[5$, p. 226].

\section{LITERATURE REVIEW}

At the present stage of development of the science of constitutional law, other definitions are given as well. S. A. Avakyan defines freedom as the independence of individual behavior, choice of actions and actions, position in the system of interpersonal, group, and public-state relations [6, p. 254].

Recently, with the complication of public communications and the forms of the exercise of the rights and legitimate interests of the individual, the role of law in the life of society has been significantly increased. Thus, the development of the Internet as one of the main ways of social connections posed new problems for legal scientists. One of them is the legal definition of the Internet in the context of international acts that establish international standards of human rights and freedoms. An attempt to resolve this issue was made by the member states of the Council of Europe in 2003. A Declaration on the Freedom of Information Exchange on the Internet was issued. This declaration normatively fixed the basic standards, using which citizens may exercise their right to use the Internet. The declaration contained provisions that were framed in seven principles. In our opinion, the following principles are the fundamental ones:

- Member States should not limit information on the Internet to a greater extent than is used in other media;

- $\quad$ public authorities should not restrict public access to information and information exchange on the Internet by applying prohibitive or restrictive measures of a general nature regardless of boundaries (this provision does not prevent the installation of filters to protect minors, particularly, in places accessible to them, such as schools or libraries); and

- $\quad$ in order to ensure protection against online surveillance and to expand the free expression of information and ideas, Member States should comply with the desire of Internet users not to reveal their identity (this provision does not prevent the Member States from taking measures and cooperating on the search for persons responsible for committing criminal actions in accordance with national legislation, the Convention for the Protection of Human Rights and Fundamental Freedoms and other international treaties in the field of justice and law enforcement).

Russian science has the same natural-legal views on this issue. Particularly, S.A. Suslikov believes, "In modern society, freedom of the mass information appears as a natural claim of people" [7, p. 92]. However, most scholars tend to believe that censorship acts as an instrument of power. Particularly, S. Korolyov believes that censorship is introduced in order to control the "thought process" of the population [8, p. 18].

In our opinion, access to the Internet should be considered as a modern prerequisite for a democratic state. Thanks to technological innovations, the population has a new platform for expressing their civic position. In addition, access to information was opened anywhere in the country and political forces should develop mechanisms for the functioning of this institution.

Throughout the history of mankind, certain tendencies toward the restriction of freedom in various forms of its manifestation can be traced. At the present stage, such an aspect of freedom as its implementation on the Internet does not work in full, which does not correspond to natural-legal concepts.

The practical experience of censorship on the Internet was first applied at the beginning of the 21 st century. In 2004, China began blocking a well-known Internet resource, Wikipedia. The reason was the availability of an article on student unrest in 1989, in which several hundred protesters died. It should also be noted that China is one of the most striking examples of countries with Internet censorship. Through the Golden Shield, a special system that controls the access of the population to certain sites, the PRC was able to create a state with an almost closed Internet system. In our opinion, this fact is a negative experience in exercising the natural right of a person to access information.

One of the arguments for introducing Internet censorship is to ensure national security and the fight against extremism. Thus, in 2001, the "Act of Patriots" was adopted in the United States, which opened up wide powers for special services to control the population on the network.

In Russia, in 2013, the President of the Russian Federation called for "blocking the attempts of radicals to use the capabilities of information technologies, Internet resources, and social media for their propaganda" [9].

In practice, it turns out that the concepts of "national security" and "extremism" are vague. These circumstances may lead to the fact that censorship in the Internet sphere is used to create a completely new form of control over the population.

Moreover, one of the main arguments for the introduction of Internet censorship is an attempt to protect children from harmful content on the network. For example, the USA adopted a set of laws that perform these functions, particularly, The Children's Internet Protection Act. Russia adopted the Federal Law "On the Protection of Children from Information that Causes Damage to Their Health and Development." In this case, "media security" acts as a 
conservative structure that delays the changing postulates of society. Such increased custody of the younger generation may have the opposite effect. John Milton wrote on this subject, "Therefore, if the cognition and vision of vice are so necessary for human virtue, and the revelation of delusions is so necessary for the cognition of truth, then in what another way it can be more truly and safely penetrate the realm of sin and lies, if not in the way of reading all kinds of treatises and listening to all kinds of arguments" $[10, \mathrm{p} .221]$. Thus, it is required not to limit minors from "adverse" content in such a violent way but to acquaint them with "vices" and learn not to succumb to the adverse phenomena of modern society.

\section{RESULTS AND DISCUSSION}

From the point of view of constitutional law, the prohibition of censorship is one of the basic tenets of freedom of speech. Freedom of speech is a condition for a more harmonious development of the personality, the revelation of its individuality.

According to the Constitution of the Russian Federation dated December 12, 1993: "Freedom of the media is guaranteed. Censorship is prohibited" (Part 5 of Article 29). Moreover, the Constitution of the Russian Federation does not contain the concept of censorship. Its legal concept was revealed in the Federal Law "On the Mass Media." The law reads, "Censorship of the media, that is, the requirement for the media editorial board by officials, government bodies, organizations, institutions, or public associations to precoordinate communications and materials (except when the official is the author or interviewee), as well imposing a ban on the distribution of communications and materials, their separate parts, is not allowed." When analyzing the Law on Mass Media, we may conclude that in the Russian Federation, both preliminary and subsequent censorship is prohibited and there is also a preventive function that does not allow censorship to be established in the future.

Freedom of speech is the foundation of natural human rights, for the reason that freedom of speech allows not only to express one's position openly, without fear of persecution but also to receive reliable and correct information freely. Various television news sources at the present stage are already far from objective. In turn, Internet sources still retain a bit of independence so they publish opinions that may not be consistent with official news sources.

Of course, we may say that the Internet, with all its possibilities of exchanging information, is also a huge warehouse of various "media garbage" but, in our opinion, this state of affairs may teach a person to correctly analyze and accept only "positive" information, without paying attention to various adverse moments on the net.

The Internet is a modern haven of freedom since there is no unified system of control by states. The Internet remains a fragmented system, which does not allow establishing control over it. And if governments are striving to limit freedom in the Internet sphere, then we may conclude that they want to limit the freedoms of the population, create a real Orwell's "Big Brother."
After analyzing the above, we may conclude that the Internet is a modern platform of freedom, it allows the population to express their thoughts and to receive true information freely. The Internet is the modern foundation of freedom and the degree of openness of the Web determines the level of freedom of society in general.

Under the conditions of the modern development of society, there is a problem of legal regulation of the order, conditions for the use of telecommunication networks and the protection of the rights and legitimate interests of various entities in the circulation of information in global computer networks.

There is an opinion that it should be considered the subject of law, legal entity, subject of legal regulation, etc. It is argued about whether to consider the Internet as a mass media. Others believe that the Internet is only an object of the law. Moreover, the answer to the question of whether the Internet can exist without social regulators and whether technical standards would be sufficient depends on how we understand the Internet as a global information and communication medium for the communication of any subjects. This raises the question of what kind of relationship in a virtual environment should be regulated by rules of law. Probably, not the Internet itself as an information and communication network but those relations, the implementation platform of which it is becoming.

It should also be borne in mind that regulatory approaches are directly related to expectations from the Internet. The idea of the Internet as a source of "unfiltered" information about the government threatens the authorities. However, officials learned to use the network in a way to avoid this. They have succeeded in promoting their interests through new media, using the Internet as an additional means of selfpromotion and restricting public access to materials that do not contribute to achieving this goal. Despite obvious conveniences, administratively the Internet is a space of freedom for a citizen but at the same time, it is really involved in the dream of individual control over citizens (creating personal data sheets and, in the future, possibly controlling political ideas and preferences).

Of course, if the state feels a threat from the Internet, it seeks to establish control over it. The world knows many approaches to regulating censorship on the Internet, from a direct ban on free access to a system of voluntary use of filtering devices by users. By analogy, the regulation of the Internet is possible depending on the specifics of the country and world experience, in different ways, from the complete self-elimination of the state to strict regulation.

Until recently, the Internet was an almost completely selfregulatory environment, in which participants in information exchange followed spontaneously established standards of behavior, a kind of "network" etiquette. The self-regulation of Internet relations is based on the rules of morality, ethics, customs, and traditions. Within the framework of self-regulation, it becomes possible to increase the adaptive efficiency of economic entities due to the fact that market participants independently establish formal rules governing this area of business, whereupon having access to local information resources. However, the 
model of absolute self-regulation of the Internet at this stage is hardly possible, therefore, it is required to find a measure of its legal regulation [11].

Experts formulate the following list of features of relations on the Internet that are important for legal regulation:

the uncertainty of the location of the parties, which causes possible problems with the applicable law, as well as with the actual fulfillment of obligations;

the difficulty of identifying participants in relationships in the network; dependence of relations between network participants on relations with information providers; and the electronic nature of the document flow in the network, which conditions the use of special software and hardware. It seems that the main "obstacle" to national legal regulation is the cross-border nature of the Internet. Indeed, Internetrelated relationships are "extra-national" in nature. The application of local rules of law to such legal relations without taking into account the link to the legislation of other states may be ineffective.

Internet regulation should consider the following points. First, it is regulated by both private and public law. In this sense, regulatory acts regarding the Internet are often complex and the separation of the right to public and private is fading into the background. Secondly, it is impossible to set limits only to national legislation since the network architecture itself is a cross-border one and most of the existing regulation is concentrated in international acts. Thirdly, the participation of private entities in the regulation of the Internet determines the existence of soft rules of law, both in international and national Internet law, which affects the classical hierarchy of sources of law based on the obligatory nature of the rule and its "state origin." Fourthly, the variety of sources of legal regulation of the Internet entails the need to develop a conflict of law in this area, which will be capable of resolving contradictions and competition of public-law and private-law rules, as well as national and international ones.

A new branch of law, which would completely regulate the totality of relations that are developing both within the Internet system and in relation thereto, should be globally unified and should operate within the entire global space. The Internet law has every chance to be designed on the model of international trade law; it is born from the cooperation of the legislator, a judge, and a user [12]. In general, in our opinion, in the field of regulating the problems associated with the emergence of new technologies (electronic digital signature, proving by means of data stored on new media), universal unification, but not regional, is preferable [13].

The worldwide nature of the Internet encourages lawyers to turn to international law in search of a solution. International law grew out of customs and mutual agreements, and the so-called soft law has become its main tool. Soft law is defined as a set of tools that meet the following conditions:

- it aims to modify or orientate the behavior of the addressees of the rules;
- $\quad$ it does not create rights and obligations for addressees; and

- in terms of content and method of development, it represents the level of formalization and structuring, which is specific for legal norms.

If at the end of the 20th century, the term "soft law" referred mainly to the sphere of regulation of international public relations, today, it also applies to the regulation of certain relations within the state, that is in national law as well. The structure of soft law is heterogeneous. There is soft law that is not recognized by customary, "hard" law (model conventions of the Organization for Economic Cooperation and Development (OECD), codes of conduct for enterprises, model contracts of professional associations), soft law that is recognized one way or another in regulatory texts or taken into account by the courts (Resolutions of the UN General Assembly). There is a gap between soft and customary law, and even in customary law, soft tools are distinguishable with "hard" law giving binding legal force to it (technical standards, codes of conduct). Sometimes such acts as a resolution, a declaration, a recommendation, a joint communique, a model law, are combined into the category of "international recommendatory acts" [14]. The acts of some international organizations that are most involved in rule-making in the field of information law, particularly, the OECD, form another component of soft law, the Guidelines on the Protection of Privacy and the Cross-Border Transfer of Personal Data, the Declaration on the Cross-Border Transfer of Data, the Cryptography Policy Guidelines, and the Declaration on the Personal Data Protection on Internet Social Media. The associations in the post-Soviet space have created their own soft law, the CIS model legislation, advisory in nature, with which its main problem is associated, not a single state uses these model laws. Meanwhile, in the information sphere, many CIS acts have been adopted, for example, the Model Law on the Fundamentals of Internet Regulation [15] or the Model Information Code [16], the rules of which are proposed to be implemented in the legal system of the Russian Federation when developing the concept of codification of the information legislation. At the same time, within the framework of the EAEU, the formation of unified information and legal space by means of creating hard law (for example, the Customs Code of the Customs Union) is being actualized, while the question of the legal nature of acts of direct action adopted by the Eurasian Commission and not provided for in Article 15 of the Constitution of the Russian Federation is not resolved. In general, a new type of legal system is being formed in interstate associations, within the framework of which imperative, indirect, and recommendatory rules are concentrated.

The country's entry into international unions and contractual relations, on the one hand, creates new information and management obligations for it, and on the other hand, contributes to the expansion of participation in the affairs of the world community. As a result, there is obtaining and using new thematic and control information, saturating our 
own decisions with foreign and international details, and modifying the lines of interaction between executive bodies with each other and with international structures.

All stakeholders should be involved in Internet governance. In this regard, it should be recognized that:

a. political powers on Internet-related public policy issues is the sovereign right of states. The latter have rights and obligations in relation to Internetrelated public policy issues at the international level;

б. the private sector plays an important role in the development of the Internet both in the technical and in the economic sphere;

B. civil society also plays an important role in Internet-related issues, especially at the community level;

г. intergovernmental organizations play a role in facilitating the coordination of Internet-related public policy issues; and

д. international organizations play an important role in the development of Internet-related technical standards and related policies.

Another problem is the correlation between international and national law. There have been three areas identified in legal science in this matter. The first one, the so-called dualistic, proceeds from the fact that international law and national law are law enforcement systems relatively isolated and independent from each other. Two other areas, called monistic, are based on the fact that international and domestic law are components of a unified system of law. At the same time, some of the advocates of this approach proceed from the recognition of priority or supremacy of national law, while others, on the contrary, insist on the primacy of international law. And here, states also have choices; which, in terms of the Internet, may present concrete obstacles to its identical functioning in different countries. In addition, while some countries recognize the right to access the Internet as a fundamental human right, others are able to "nationalize" its use.

In general, the most promising lawyers see such a model for regulating the Internet, in which the intergovernmental (public law) structure is only a general framework and the private sector takes up the main, practical issues in the field of rulemaking, legal proceedings, enforcement, and technical decisions. This applies to the distinction between the areas of responsibility of public and private subjects, where certain experience in collaboration has already been accumulated. But with regard to the distribution of the burden of national and international regulation, special risks are noted, particularly, the real danger of fragmentation of the Internet within national borders, which will undermine the integrity, universality, compatibility, and cross-border nature of the Internet and may destroy the multilateral model of Internet governance that has developed over the past 15 years. Internet regulation provides an opportunity for a new regulatory organization of public administration, where the results of agreements between state and non-state actors may take on a special legal form.

Currently, federal law stipulates that the organizer of the dissemination of information on the Internet should store the following in the territory of the Russian Federation:

- information on the facts of reception, transmission, delivery, and processing of voice information, written text, images, sounds, video, or other electronic messages from Internet users and information about these users within one year from the date of completion of such actions;

- text messages from Internet users, voice information, images, sounds, video, and other electronic messages from Internet users up to six months from the date of their reception, transmission, delivery, and processing.

Moreover, the organizer of the dissemination of information on the Internet is obliged to provide information to authorized state bodies engaged in operative and search activities or ensuring the security of the Russian Federation. Moreover, the organizer of the dissemination of information on the Internet is obliged to ensure the implementation of requirements established by the federal executive body in the field of communications in coordination with authorized state bodies engaged in operative and search activities or ensuring the security of the Russian Federation, requirements for equipment, software and hardware used by the indicated organizer in the information systems operated by it in order to allow these bodies to perform actions to implement the tasks assigned to them, as well as to take measures to prevent the disclosure of organizational and tactical methods of carrying out these actions, in the cases established by federal laws.

When using the additional encoding of electronic messages for receiving, transmitting, delivering and processing electronic messages from Internet users and when providing Internet users with the possibility of additional encoding of electronic messages, the organizer of the dissemination of information on the Internet should submit the information required for decoding received, transmitted, delivered, and processed electrons messages to the federal executive body security domain ensuring the state security.

In the case of activities to ensure the functioning of information systems and programs for electronic computers that are designed and used for the exchange of electronic messages, the organizer of the dissemination of information on the Internet should:

- identify users of the Internet, the electronic messaging of which are carried out by the organizer of the instant messaging service 
through the subscriber number of the mobile radiotelephone operator;

- within one day from the moment of receipt of the corresponding requirement of the federal executive body, limit the possibility of the user of the instant messaging service to send electronic messages containing information, the distribution of which is prohibited in the Russian Federation;

- $\quad$ provide the technical ability of users of the instant messaging service to refuse to receive electronic messages from other users;

- $\quad$ ensure the confidentiality of transmitted electronic messages;

- $\quad$ provide the ability to transmit electronic messages at the initiative of state bodies in accordance with the legislation of the Russian Federation; and

- $\quad$ prevent the transmission of electronic messages to users of the instant messaging service [17].

\section{CONCLUSION}

Taking into account all certainly positive aspects that make society more open, free, and modern, the Internet also includes a very dangerous segment generating a high degree of vulnerability of public and state interests.

The rapid development of information and communication technologies allows terrorists to expand the geography of their destructive ideology, to recruit and attract financial resources, to carry out hacker attacks and other cybercrimes more actively. In this regard, closer cooperation is required between government agencies, the technology sector, and religious leaders in using online platforms to advance arguments aimed at preventing the radicalization of the most vulnerable groups and individuals.

It should be borne in mind that today, actually, the global Network is the main most effective mechanism for managing scattered forces and means for terrorists, including financial ones. They actively create new ones and wake up the so-called sleeping units, organize the collection of financial resources, and form their own cyber divisions. In these conditions, the preservation of disputes between countries in assessments and approaches to the role and place of the global network in public life is unacceptable. It is irresponsible to create an own parallel universe, free from law and morality. A broad international dialogue is needed to counter the use of the Internet by terrorists at various international platforms.

Thus, today, regulatory activity in the virtual environment continues. And in general, it can be said that most states are trying to clearly establish the framework of what is permitted on the Internet, to determine the types of responsibilities for offenses in this area, and to establish sanctions at the legislative level.

\section{REFERENCES}

[1] Bayeva, Ye.O. Tsenzura i yeye vliyaniye na kul'turu obshchestva / Ye.O. Bayeva // Unikal'nyye issledovaniya XXI veka. - 2015. - №11. - S. 8891.

[2] Levchenko, I.Ye. Paradoksy tsenzury / I.Ye. Levchenko // Tsenzura v Rossii: istoriya i sovremennost'. - 2005. - №2. - S. 172-182.

[3] Grechkosey, R.N. Ponyatiye svobody v filosofii E. Fromma i F.Nitsshe kak proyavleniye chelovecheskoy sushchnosti / R.N. Grechkosey // Molodoy uchenyy. 2013. - №10. - S. 634-640.

[4] Gaydareva I.N., Problema internet-tsenzury v kontekste ogranicheniya svobody slova // I.N. Gaydareva, M.A. Yeshev, G.A. Blagova, N.O. Leonov // Agrarnoye i zemel'noye pravo. - 2017. - № 1 (145). - S. 149-152.

[5] Frantsuzskaya Respublika. Konstitutsiya i zakonodatel'nyye akty. / pod red. Chirkina V. Ye. - M. : Progress, 1989. - 448 s.

[6] Avak'yan, S.A. Konstitutsionnoye pravo Rossii v 2 t. / S.A. Avak'yan. - M., 2005. T. 1. - 870 s.

[7] Suslikov, S.A. Konstitutsionno-pravovoye regulirovaniye sredstv massovoy informatsii $\mathrm{v}$ Rossiyskoy Federatsii: avtoref. dis. kand. yur. nauk / S.A. Suslikov. - Saratov, 2007. - 188 s.

[8] Korolev, S. Plagiat kak alter ego tsenzury / S. Korolev // Indeks. - 2004. - №20. - S. 17-21.

[9] Putin trebuyet blokirovat' propagandu radikalov v Internete. [Elektronnyy resurs] URL: http://ria.ru/defense_safety/20130214/922893177.html. (Data obrashcheniya: 24.07.2019).

[10] Fokin, A.A. Ayeropagitika 2.0. Vystupleniye protiv Internet-tsenzury / A.A. Fokin // Vestnik Chelyabinskogo gosudarstvennogo universiteta. - 2013. - №22 . - S. 219-222. 
[11] Talapina, E.V. O vozmozhnostyakh pravovogo regulirovaniya interneta. Trudy instituta gosudarstva i prava RAN / E.V. Talapina. - M., 2016.

[12] Fauchoux, V. Le droit de l'internet. Lois, contrats et usages / V. Fauchoux, P. Deprez. - P., 2008. - P. 6.

[13] Lezhe, P. Velikiye pravovyye sistemy sovremennosti / R. Lezhe. Per. s fr. - M., 2010. - S. 511.

[14] Kashirkina, A.A. Mezhdunarodnyye rekomendatel'nyye akty v rossiyskoy pravovoy sisteme: predely i vozmozhnosti ispol'zovaniya / A.A. Kashirkina, A.N. Morozov // Zhurnal rossiyskogo prava. - 2015. - № 2. - S. 139.

[15] Ob osnovakh regulirovaniya Interneta: model'nyy zakon SNG: prinyat v g. Sankt-Peterburge 16 maya 2011 g. (postanovleniye 36-9 na 36-m plenarnom zasedanii Mezhparlamentskoy assamblei gosudarstv - uchastnikov SNG) // Informatsionnyy byulleten'. Mezhparlamentskaya assambleya gosudarstv uchastnikov SNG. - 2011. - № 51. - S. 191-198.

[16] Model'nyy informatsionnyy kodeks dlya gosudarstv-uchastnikov SNG: prinyat v g. SanktPeterburge 23 noyabrya 2012 g. (postanovleniye 38-6 na 38-m plenarnom zasedanii Mezhparlamentskoy assamblei gosudarstv - uchastnikov SNG) // Informatsionnyy byulleten'. Mezhparlamentskaya assambleya gosudarstv - uchastnikov SNG. - 2013. - № 57 (ch. 1). - S. 44-73.

[17] Ob informatsii, informatsionnykh tekhnologiyakh i o zashchite informatsii: feder.zakon ot 27 iyulya $2006 \mathrm{~g}$. № 149-FZ // Sobraniye zakonodatel'stva Rossiyskoy Federatsii. - 2006. - № 31 (ch.1). - St. 3448. 